December 2019

\title{
Public Libraries Supporting Health and Wellness: A Literature Review
}

Heather Elia

Syracuse University School of Information Studies, hlelia@syr.edu

Follow this and additional works at: https://scholarworks.sjsu.edu/ischoolsrj

Part of the Library and Information Science Commons

\section{Acknowledgements}

The author would like to acknowledge the help and support of Jill Hurst-Wahl, associate professor of practice at Syracuse University's School of Information Studies, for her mentorship and helpful feedback during the writing of this article.

\section{Recommended Citation}

Elia, H. (2019). Public Libraries Supporting Health and Wellness: A Literature Review. School of Information Student Research Journal, 9(2). https://doi.org/10.31979/2575-2499.090207 Retrieved from https://scholarworks.sjsu.edu/ischoolsrj/vol9/iss2/7

This article is brought to you by the open access Journals at SJSU ScholarWorks. It has been accepted for inclusion in School of Information Student Research Journal by an authorized administrator of SJSU ScholarWorks. For more information, please contact scholarworks@sjsu.edu. 


\title{
Public Libraries Supporting Health and Wellness: A Literature Review
}

\begin{abstract}
The purpose of this literature review is to examine the ways in which public libraries are supporting the health and wellness needs of their communities. Although public libraries are not commonly thought of in association with healthcare, research shows that many libraries are partnering with other community organizations and healthcare professionals to provide programs and services intended to address the health and wellness needs of their patrons. Using scholarly journals, as well as trade and news publications, the author investigated numerous methods of health-themed service provision, including: consumer health information, embedded professionals, visiting health services, mental health support, wellness-based programming, and responses to the opioid crisis. Details on these programs are provided in this review so that readers can build upon existing ideas when considering their own health and wellness service offerings. Future work connected with this topic should involve a discussion of how to increase successful partnerships between libraries and other health-based organizations, how best to obtain funding for health and wellness public library initiatives, and how to publicize library health and wellness offerings to maximize their utilization by the public.
\end{abstract}

\section{Keywords}

health, wellness, public libraries, consumer health information, opioid crisis, social services

\section{Acknowledgements}

The author would like to acknowledge the help and support of Jill Hurst-Wahl, associate professor of practice at Syracuse University's School of Information Studies, for her mentorship and helpful feedback during the writing of this article.

\section{About Author}

Heather Elia is a Master of Science in Library and Information Science (MSLIS) student at the Syracuse University School of Information Studies. She is a member of the school's iSchool Public Libraries Initiative (IPLI) and a recipient of the Wilhelm Library Leadership Award. 
On July 12, 2018, two library staff members at Emily Fowler Central Library in Denton, Texas saved a man's life. By performing CPR and using an automated external defibrillator on an unconscious patron, they kept the man alive while waiting for paramedics to arrive (Perez, 2018). Librarians across the country are also "saving lives in the stacks" by being trained to use Narcan to counteract opioid overdoses in their workplaces (Ford, 2017). These are just two examples of public libraries supporting the health and wellness needs of their communities; there are many more. Although public librarians are not medical professionals, and public libraries are not medical buildings, they nevertheless have a long history of supporting the physical, mental, and social health of their patrons.

Morgan et al. (2016) argued that although public libraries are not often given a seat at the table when discussing community wellness, they are "well positioned to be partners in building a culture of health." Indeed, public libraries possess multiple characteristics that make them ideal participants in the public health arena: they are trusted institutions, widely used by the public, and exist in most communities around the country, whether urban, suburban, or rural (Philbin, Parker, Flaherty, \& Hirsch, 2019).

A review of scholarly and trade publications from the past six years, as well as recent news stories, highlight the role of public libraries as providers of community health and wellness information, services, and programs. The current trends in the literature are to share best-practices for how public libraries are forwarding community health, to highlight the challenges of providing healthbased services, and to identify the barriers preventing librarians from offering these services, including a lack of knowledge and comfort on the part of librarians in offering these services. The literature also tends to focus on questions raised both within and outside the LIS profession about whether public libraries should be involved with public health concerns at all, and if so, how.

Regardless of the challenges, public libraries are increasing their efforts to promote health and wellness in their communities, especially in the following areas: consumer health information provision, embedded professionals, mental health, health-based programs, and the opioid crisis. Successful programs and services at individual libraries result from strong partnerships with local healthbased organizations, as well as collaborations at a national level to address wideranging health concerns like the opioid epidemic.

\section{Consumer Health Information Provision}

As the Reference and User Services Association (2015) has made clear in their guidelines on health and medical reference, librarians are not healthcare professionals and should not "interpret or make recommendations regarding diagnoses, treatments, or specific health care professionals or health care facilities." Yet public libraries are locations that patrons often go to in order to seek health care information. According to a Pew Research Center survey, $73 \%$ of people aged $16+$ believe that libraries are important to people looking for health information, and $42 \%$ who have used a library's technological resources have done so to pursue health-related inquiries (Horrigan, 2015). As many as 93.8\% of librarians encounter health-related questions at the reference desk (Luo \& Park, 2013). It is the duty of library staff to respond to users' requests and provide 
"assistance with identifying and finding relevant, credible, and authoritative sources to answer users' questions" (Reference and User Services Association, 2015). Thus, librarians should be prepared to help patrons identify and locate quality resources when answering consumer health information queries.

Several studies indicate that barriers to providing this type of assistance often include lack of comfort or knowledge on the part of library staff surrounding authoritative health information sources (Luo \& Park, 2013 and Rubenstein, 2016a). One way to overcome these obstacles is through successful public library partnerships with academic institutions and/or local healthcare organizations (Clifton, Jo, Longo, \& Malone, 2017, Engeszer et al., 2016 and Ports et al., 2015). Working in conjunction with external partners such as a medical center, health library, or a local department of health can lead to outcomes where public library staff become better trained to respond to, and more comfortable answering, patron questions related to health and wellness.

Another way that librarians are increasing their expertise in answering consumer health information requests is through the Medical Library Association's Consumer Health Information Specialization (CHIS) certification program. Librarians with CHIS certification are more confident and prepared when directing patrons to authoritative health resources (Clifton, Jo, Longo, \& Malone, 2017, Ports et al., 2015, Rubenstein, 2016a, Rubenstein, 2016b, and Rubenstein, 2018). These librarians often become the resident experts on medical questions in their libraries and are valued both by patrons and other staff members, with whom they share what they learned in their CHIS courses (Rubenstein, 2016b).

\section{Embedded Professionals}

As stated earlier, public librarians are not healthcare workers, and most know when they have reached the limits of their professional abilities on health-related requests. In recent years, several public libraries have addressed the health and wellness needs of their patrons by hiring social workers, nurses, and other professionals as an official part of the staff to address issues that librarians may not be qualified to tackle.

Social workers as public library employees are not an entirely new idea. In 2009, the main branch of the San Francisco Public Library became the first library in the country to hire a psychiatric social worker as a full-time member of their staff (Knight, 2010). Since then, an estimated 30 additional public libraries have followed suit (Janis, 2018). Homelessness is frequently, although not exclusively, the topic that most public library social workers deal with, whether directly through outreach and casework, or more fundamentally through exploring and addressing the institutional and systemic causes of homelessness in a given community (Dankowski, 2018). Social workers may provide support to other vulnerable populations, such as low-income individuals seeking to access social services like food stamps and Medicaid. Many social workers offer training to library staff in how to sensitively interact with patrons with a variety of needs (Dankowski, 2018 and Janis, 2018). Library social workers may serve in a supervisory capacity, overseeing other social workers on staff, or even hiring formerly homeless patrons as peer counselors to assist with their work ("Great 
Big Story", n.d. and Knight, 2010). In addition to dealing with homelessness and poverty, social workers may be expected to address the mental health needs of patrons and their families (Steiner, 2018).

Social workers are not the only health and wellness professionals to find their place on a public library staff. The Pima County Public Library in Tucson, Arizona has hired a registered nurse to assist patrons at the main library building (Monaghan, 2016). A partnership between the public library and the Pima County Health Department, the Library Nurse Program developed to realize the following goals: perception by patrons and staff of the library as a "safe and welcoming" place, and provision of "health-promoting education and services" to library patrons (Malkin \& Feingold, 2014, p. 560). The public health nurse helps to achieve these goals by providing intervention when patrons become disruptive or need medical care. She also trains other library staff in ways to help de-escalate problematic patron encounters, administers flu vaccines, helps patrons sign up for health insurance, and works with other community partners to institute an afterschool snack program for approximately 300 children.

Challenges that libraries face when considering hiring embedded professionals include a lack of qualified health providers in the community, difficulties in liaising with local health departments (Malkin \& Feingold, 2014), as well as concerns about patrons' privacy (Dankowski, 2018). Successful programs with embedded professionals have involved strong partnerships with local social service providers and a concerted effort in getting to know specific community needs (Dankowski, 2018 and Steiner, 2018).

\section{Mental Health}

Mental health is another area in which libraries are supporting their communities. With nearly 1 in 5 U.S. adults suffering from mental illness (National Institute of Mental Health, n.d.), it stands to reason that a public library's patron population will be comprised of those with mental health conditions who seek to access the library's space and resources.

A public library that provides a safe, open, and welcoming atmosphere is often seen as a "therapeutic landscape" (Brewster, 2014, p. 94) by those with mental health issues - a calming, comforting place to go when feelings of distress threaten to overwhelm them and an empowering location to seek education, resources, and community. Library staff's supportive behavior towards people with mental illness plays an important role in promoting this sort of beneficial atmosphere.

Some public libraries have been proactive in providing mental health and wellbeing information services, working collaboratively with other local organizations to support community mental health projects and sponsoring weekly discussion groups to reduce loneliness and isolation (Lungley, 2016). In other public libraries, staff are unsure how best to deal with patrons experiencing mental health crises, especially when those patrons become disruptive or combative (Peet, 2019).

A solution to this lack of knowledge/comfort in interacting with mentally ill patrons is Mental Health First Aid training for library staff. This training helps participants identify the signs of mental illness and substance abuse with the 
intent of destigmatizing these conditions and providing guidance in how to initiate conversations with patrons who may be in crisis and need referral to mental health services (Hubert, 2018). Although not meant to be a substitute for professional mental health treatment, Mental Health First Aid has been used successfully by public libraries to defuse difficult patron interactions and assist both adults and teens with mental health concerns (Throgmorton, 2017).

Other libraries offer more casual mental health assistance. Luck Public Library in Wisconsin offers a weekly mindfulness program hosted by a library staff member (Ruhlmann, 2017). The program, called "Breathe," is a guided practice that requires no prior experience and is open to everyone (Luck Public Library, n.d.) Many libraries use the services of therapy dogs - canines that are specially trained to provide psychological support - as a calm and friendly listening ear for young readers, although other libraries have extended their therapy dog programs to reach teens as well (Whittall, 2017).

Regardless of the level of mental health support a public library offers, the literature highlights the importance of making connections with local mental health organizations (Berk, 2015, Lumley, 2016 and Peet, 2019). It is important to note that there may be challenges from other patrons, administrators, and funding authorities, who feel that the library is not the proper place to be addressing mental health issues beyond calling security when a patron is disruptive (Berk, 2015 and Peet, 2019). However, the literature shows that patrons with mental illness benefit when library staff are caring, non-judgmental, and provide support within appropriate boundaries (Berk, 2015, Brewster, 2014, Lungley, 2016, Peet, 2019 and Throgmorton, 2017).

\section{Health-Based Programs}

One of the most common ways that libraries support community health and wellness is by offering health-based programs and materials to their patrons. There is an almost infinite numbers of ways that public libraries, of all sizes and in all locations, can support wellness through the programs and resources they offer. The benefits not only include the improved health of the community, but attracting new users to the library (Lenstra, 2017 and Pyatetsky, 2016).

Library staff cite many reasons for providing health-based programs: as a response to national and regional trends in the library profession, in reaction to patron preferences and needs, and as a result of their staff members' personal interest in the physical activity (Lenstra 2018). Patron needs may come into play in regions known for high obesity rates and lack of healthcare (Flaherty \& Miller, 2016) or in communities where activity levels are not equal across demographics (McCarty, 2018).

According to a 2014 survey, approximately $48 \%$ of public libraries offer programs geared towards helping patrons understand specific health and wellness topics (Bertot et al., 2015). Such offerings include weight-loss programs (Flaherty $\&$ Miller, 2016), healthy cooking demonstrations (Ewen, 2018 and Pyatetsky, 2016), pre-natal classes and sessions on cancer (Wahowiak, 2018), workshops on living a healthy lifestyle and disease prevention (Luo, 2018) and more. The success of these programs is often dependent on strong partnerships with local and regional health organizations (Luo, 2018 and Wahowiak, 2018), including 
city and county health departments, hospitals, other health centers, and the National Network of Libraries of Medicine.

Although most commonly associated with foundational, digital, and information literacy, public libraries are beginning to address kinetic or physical literacy as well. Physical literacy is supported by movement-based programs for all ages, which can be offered casually — in the form of a bean-bag toss in the children's area or a mini basketball hoop in the teen section- or more formally through weekly fitness classes for adults (Carson, 2015). Movement-based classes in public libraries run the gamut from yoga, which is the most frequently offered (Lenstra, 2017), to more unusual activities like Punk Rock Aerobics and Zombie Survival Fitness (Pyatetsky, 2016). Other popular programs include movementbased early literacy sessions, Story Walk® activities, gardening, and dancing (Lenstra, 2017). Collaborations with outside organizations in the communityincluding running stores, universities, and fitness instructors - are as important for the success of movement-based programs as they are for informational programs (Flaherty \& Miller, 2016; Luo, 2018; McCarty, 2018).

In addition to providing activities for a variety of ages, from toddlers to senior citizens (Lenstra, 2017 and Luo, 2018), it is crucial for libraries to vary their program formats to reach as wide an audience as possible. Library staff must be mindful in working to overcome the barriers to attendance presented by differing health needs and fitness levels and being inclusive in terms of demographics like race and ethnicity (Luo, 2018). Public libraries must also navigate the challenges associated with offering health related programs, including logistical and financial considerations, worries about liability, and the potential that administrators might not view health-related programs as being the province of a public library.

\section{Opioid Crisis}

One aspect of health and wellness that has been in the media recently is the response of public libraries to the opioid crisis. Increasingly, library staff have had to deal with concerns such as discarded needles and drug usage in the building. Overdoses and fatalities from the use of opioids in libraries has led many public libraries to respond by stocking Narcan - a drug that can reverse the effects of an opiate overdose - and by offering training to their staff about how to use it (Bump, 2018, Correal, 2018, Ford, 2017, Freudenberger, 2019, and "Libraries become unlikely front", 2018.)

Besides offering staff training on the use of Narcan, other libraries are offering community programs and hosting speakers to educate the public about opiate addiction (Dankowski, 2019 and "Library Notes," 2018). Some libraries are even providing Narcan training sessions to the general public (Brown, 2018 and Freudenberger, 2019).

As with other ways of supporting health and wellness in public libraries, much of the literature on the opioid crisis highlights the importance of strong community partnerships in dealing with this public health issue (Dankowski, 2019, Freudenberger, 2019, and OCLC, 2018). Collaborations with medical professionals, addiction counselors, local departments of health, and state 
government agencies increase the impact that public libraries can make in this arena (Freudenberger, 2019.)

The trend of public libraries addressing the opioid crisis is seen by many as an essential step in supporting community health. However, the practice is not without its critics. Some library staff have been criticized by their peers for choosing to administer Narcan, claiming it's "not part of the job" for librarians to be responsible for life-or-death medical treatment (Ford, 2019). Librarian Fobazi Ettarh is concerned about mission creep in libraries, especially as it pertains to Narcan administration. She has argued that the education librarians receive does not include medical or social work training. Ettarh also argues that libraries as institutions are not designed to support librarians through the trauma they might face by dealing with issues like opioid overdoses or fatalities (Ford, 2019).

In spite of these concerns, the role of public libraries in combating the opioid crisis is considered so crucial that the Institute of Museum and Library Services has awarded OCLC a nearly $\$ 250,000$ grant to "collect and share knowledge and resources to support public libraries and their community partners" in addressing this public health issue (OCLC, 2018). OCLC will work with the Public Library Association to develop case studies, a white paper, webinars, and other materials related to the topic for public library use.

\section{Conclusion}

Public libraries have been contributing to the wellness of their communities for some time, and opportunities to offer these kinds of health-based services have increased in recent years. Some of the most frequent offerings include consumer health information provision. The use of embedded professionals, such as social workers, nurses, and peer counselors, has become popular. Public libraries work with outside organizations to promote both mental and physical wellness. The opioid crisis is a recent area of concern, and an increasing number of public libraries are beginning to include the potentially life-saving administration of Narcan among their service provisions. The scholarly, trade, and news literature shows that public libraries are an important resource when considering the health and wellness needs of a community. Public librarians should advocate for a seat at the table in community conversations about public health. Recommended future work connected with this topic should involve a discussion of how to leverage successful partnerships between libraries and other health-based organizations, how best to obtain funding for health and wellness public library initiatives, and how to publicize library health and wellness offerings to maximize their utilization by the public. 


\section{References}

Berk, J. (2015, January 5). Mental health training in public libraries. Public Libraries Online. Retrieved from http://publiclibrariesonline.org/2015/01/mental-health-training-in-publiclibraries/

Bertot, J. C., Real, B., Lee, J., McDermott, A. J., \& Jaeger, P. T. (2015). 2014 Digital Inclusion Survey: Survey Findings and Results. University of Maryland, College Park: Information Policy \& Access Center (iPAC). Retrieved from https://digitalinclusion.umd.edu/sites/ default/files/uploads/2014DigitalInclusionSurveyFinalRelease.pdf

Brewster, L. (2014). The public library as therapeutic landscape: A qualitative case study. Health and Place, 26, 94-99. http://doi.org/10.1016/j.healthplace.2013.12.015

Brown, C. (2018, October 10). At the library: Learn how to help with the opioid crisis. The New Orleans Advocate. Retrieved from http://nola.com

Bump, B. (2018, August 20). Capital Region librarians are unlikely heroes in fight against opioids. Times Union. Retrieved from https://www.timesunion.com

Carson, J. (2015, August 19). Kinetic literacy. Programming Librarian. Retrieved from http://www.programminglibrarian.org/blog/kinetic-literacy

Clifton, S., Jo, P., Longo, J. M., \& Malone, T. (2017). Cultivating a community of practice: The evolution of a health information specialists program for public librarians. Journal of Medical Library Association, 105, 254-261. http://doi.org/10.5195/JMLA.2017.83

Correal, A. (2018, February 28). Once it was overdue books. Now librarians fight overdoses. New York Times. Retrieved from http://nytimes.com

Dankowski, T. (2018, March 21). A social worker walks into a library: Public libraries are using licensed professionals to address homelessness and mental health issues. American Libraries. Retrieved from https://americanlibrariesmagazine.org/blogs/the-scoop/pla-social-workerwalks-library/

Dankowski, T. (2019, June 25). Addressing the opioid epidemic: Public libraries are crafting harm reduction responses with community partners. American Libraries. Retrieved from https://americanlibrariesmagazine.org/blogs/the-scoop/addressing-opioidepidemic/ 
Engeszer, R. J., Olmstadt, W., Daley, J., Norfolk, M., Krekeler, K., Rogers, M., \& Williams, L. (2016). Evolution of an academic-public library partnership. Journal of the Medical Library Association, 104(1), 62-66. http://doi.org/10.3163/1536-5050.104.1.010

Ewen, L. (2018, September 4). A movable feast: Libraries use mobile kitchens to teach food literacy. American Libraries. Retrieved from https://americanlibrariesmagazine.org/2018/09/04/movable-feast-librarymobile-kitchens/

Flaherty, M. G., \& Miller, D. (2016). Rural public libraries as community change agents: Opportunities for health promotion. Journal of Education for Library and Information Science, 57, 143-150. http://doi.org/10.12783/issn.2328-2967/57/2/6

Ford, A. (2017, June 21). Saving lives in the stacks: How libraries are handling the opioid crisis. American Libraries. Retrieved from https://americanlibrariesmagazine.org/2017/06/21/saving-lives-in-the-stacks/

Ford, A. (2019, Other duties as assigned: Front-line librarians on the constant pressure to do more. American Libraries. Retrieved from https://americanlibrariesmagazine.org/2019/01/02/mission-creep-other-dutiesas-assigned/

Freudenberger, E. (2019, May 7). Not just Narcan. Library Journal. Retrieved from https://www.libraryjournal.com/?detailStory=Not-Just-Narcan

Great Big Story. (n.d.). In Denver, fighting homelessness at the library. Retrieved from https://www.greatbigstory.com/stories/defenders-opioids-homelessnesscuica-montoya

Horrigan, J. B. (2015 September 15). Libraries at the crossroads. Retrieved from http://www.pewinternet.org/2015/09/15/libraries-at-the-crossroads/

Hubert, C. (2018, January 29). The unexpected role librarians are playing in Sacramento's homeless crisis. Sacramento Bee. Retrieved from https://www.sacbee.com

Janis, J. (2018, June 11). Public library social work: An emerging field. Retrieved from http://naswil.org/news/chapter-news/featured/ public-library-social-work-an-emerging-field/

Knight, H. (2010, January 11). Library adds social worker to assist homeless. San Francisco Chronicle. Retrieved from http://sfgate.com 
Lenstra, N. (2017). Movement-based programs in U.S. and Canadian public libraries: Evidence of impacts from an exploratory survey. Evidence Based Library and Information Practice, 12, 214-232.

http://doi.org/10.18438/B8166D

Lenstra, N. (2018). The experiences of public library staff developing programs with physical activities: An exploratory study in North Carolina. The Library Quarterly, 88, 142-159. http://doi.org/10.1086/696580

Libraries become unlikely front in opioid epidemic. (2018, July 30). Retrieved from http://bronx.news12.com/story/38769867/

libraries-become-unlikely-front-in-opioid-epidemic

Library notes: Library programs to address opiate addiction. (2018, October 1). Retrieved from http://www.advertiser-tribune.com/ opinions/local-columns/2018/10/library-notes-library-programs-to-address -opiate-addiction/

Luck Public Library. (n.d.) Adult programs. Retrieved from https://luckpubliclibrary.org/node/3

Lungley, S. (2016, June). New chapter for mental health and wellbeing. CILIP Update, 34-35. Retrieved from https://cilip.pagelizard.co.uk/webviewer/\#cilipupdatejune2016/Page/34

Luo, L. (2018). Health information programming in public libraries: A content analysis. Public Library Quarterly, 37, 233-247. http://doi.org/10.1080/01616846.2018.1498704

Luo, L., \& Park, V. T. (2013). Preparing public librarians for consumer health information service: A nationwide study. Library and Information Science Research, 35, 310-317. https://doi.org/10.1016/j.lisr.2013.06.002

Malkin, K. B. \& Feingold, S. K. (2014, December). A library, a nurse, and good health. Computers, Informatics, Nursing, 32, 559-561.

McCarty, A. (2018, August 21). Fitting fitness into library programming. Public Libraries Online. Retrieved from http://publiclibrariesonline.org/2018/08/fitting-fitness-into-libraryprogramming/

Monaghan, E. M. (2016). The library is in. Library Journal.

Retrieved from https://www.libraryjournal.com/?detailStory=the-library-is-in 
Morgan, A. U., Dupuis, R., D’Alonzo, B., Johnson, A., Graves, A., Brooks, K. L., McClintock, A., Klusaritz, H., Bogner, H., Long, J. A., Grande, D., \& Cannuscio, C. C. (2016). Beyond books: Public libraries as partners for population health. Health Affairs, 35, 2030-2036. http://doi.org/10.1377/hlthaff.2016.0724

National Institute of Mental Health. (n.d.). Mental illness. Retrieved from https://www.nimh.nih.gov/health/statistics/mental-illness.shtml

OCLC. (2018, October 2). OCLC awarded IMLS grant to help public libraries, partners respond to opioid epidemic. Retrieved from https://www.oclc.org/en/news/releases/2018/20181002-oclc-awarded-imlsgrant.html

Peet, L. (2019, June 11). Mental wellness. Library Journal. Retrieved from https://www.libraryjournal.com/?detailStory=Mental-Wellness

Perez, Z. (2018, July 31). Library staffers to be recognized for helping save man's life. Denton Record-Chronicle. Retrieved from http://dentonrc.com

Philbin, M. M., Parker, C. M., Flaherty, M. G., \& Hirsch, J. S. (2019). Public libraries: A community-level resource to advance population health. Journal of Community Health, 44, 192-199. http://doi.org/10.1007/s10900-018-0547-4

Ports, K. A., Ayers, A., Crocker, W., Hart, A., Mosavel, M., \& Rafie, C. (2015). Community perceptions and utilization of a consumer health center. Journal of the Medical Library Association, 103(1), 35-39. http://doi.org/10.3163/1536-5050.103.1.007

Pyatetsky, J. (2016, November 1). Promoting health and fitness literacy at the library. Public Libraries Online. Retrieved from http://publiclibrariesonline.org/2016/11/promoting-health-and-fitness-literacy -at-the-library/

Reference and User Services Association. (2015, June). Health and medical reference guidelines. Retrieved from http://www.ala.org/rusa/resources/guidelines/guidelinesmedical

Rubenstein, E. L. (2016a). Breaking health barriers: How can public libraries contribute? Public Library Quarterly, 35, 331-337. http://doi.org/10.1080/01616846.2016.1245006

Rubenstein, E. L. (2016b). Health information and health literacy: Public library practices, challenges, and opportunities. Public Library Quarterly, 35(1), 49-71. http://doi.org/10.1080/01616846.2016.1163974 
Rubenstein, E.L. (2018). "I want to provide patrons with good information": Public library staff as health information facilitators. The Library Quarterly, 88(2). http://doi.org/10.1086/696579

Ruhlmann, E. (2017, June 1). Mindful librarianship. American Libraries. Retrieved from https://americanlibrariesmagazine.org/2017/06/01/mindful-librarianship/

Steiner, A. (2018, February 7). New library social worker will help patrons access mental health supports. MinnPost. Retrieved from http://minnpost.com

Throgmorton, K. (2017, March 1). Mental health first aid: Training librarians to help patrons in crisis. American Libraries. Retrieved from https://americanlibrariesmagazine.org/2017/03/01/mental-health-first-aid/

Wahowiak, L. (2018, October). Libraries, public health work together on community health: Settings serve as community hubs. The Nation's Health. Retrieved from http://thenationshealth.aphapublications.org/content/48/8/1.2

Whittall, C. (2017, December 28). Hang with Jake: Therapy dogs and teens. Programming Librarian. Retrieved from http://programminglibrarian.org/blog/hang-jake-therapy-dogs-teens 